УДК 343.13

Н. П. Сиза

orcid.org/0000-0001-5850-4023

кандидат юридичних наук, доцент,

доцент кафедри крилінального процесу та криліналістики

Київського національного університету ілені Тараса Шевченка

\title{
РЕАЛІЗАЦІЯ СУДОМ КРИМІНАЛЬНО-ПРОЦЕСУАЛЬНИХ ФУНКЦІЙ НА СТАДІЇ ПІДГОТОВЧОГО ПРОВАДЖЕННЯ
}

Постановка проблеми. Реалізація судом кримінально-процесуальних функцій на стадії підготовчого провадження спрямована на виконання як її спеціальних завдань, так і загальних завдань кримінального провадження. Ефективність судової діяльності в будь-якій стадії зумовлена наявністю у суду повноважень для здійснення його функцій, а також встановленням належної процесуальної форми їх реалізації. у зв’язку з цим існує необхідність у з'ясуванні відповідності норм чинного Кримінального процесуального кодексу України (далі - КПК), які регламентують підготовче провадження, функціональному призначенню діяльності суду в цій стадії та виявленні законодавчих прогалин, які потребують усунення.

Аналіз останніх досліджень i публікацій. Дослідженню сучасних проблем процесуальної регламентації стадії підготовчого провадження присвячені роботи О.В. Бабаєвої, В.І. Галагана, O.I. Галагана, I.В. Гловюк, В.О. Гринюка, C.I. Дячука, О.В. Єні, В.В. Луцика, Л.Г. Матієк, Ю.М. Мирошниченка, В.О. Попелюшка, М.П. Тахтарова, О.Ф. Шминдрук, Д.О. Шумейка та інших вчених. Роботи зазначених авторів містять важливі теоретичні положення, аналіз чинного законодавства та практики його застосування і є основою для подальшої розробки проблем кримінального провадження, зокрема і в аспекті реалізації судом кримінально-процесуальних функцій на стадії підготовчого провадження.

Мета статті - на основі розгляду теоретичних положень і правозастосовної практики розкрити особливості реалізації судом кримінально-процесуальних функцій на стадії підготовчого провадження та визначити пропозиції для вдосконалення окремих положень КПК в частині регламентації повноважень суду на цій стадії.

Виклад основного матеріалу. У науці кримінального процесу кримінально-процесуальні функції визначають як окремі види, окремі напрями кримінально-процесуальної діяльності [1, с. 188-189] як виражені у відповідних напрямах діяльності спеціальне призначення і роль i учасників [2, с. 55], як результат сумісної дії позиції суб'єкта і спрямованої на їі реалізацію діяльності [3, с. 4], як виражені в законі основні на- прями процесуальної діяльності [4, с. 13], а також як закріплені в законі основоположні підсистемні види (частини, компоненти, напрями) кримінально-процесуальної діяльності [5, с. 67]. Зазначені позиції дають змогу стверджувати про існування системи кримінально-процесуальних функцій, до яких належать три основні функції (обвинувачення, захист і правосуддя) та функції суб'єктів кримінального провадження.

Кримінально-процесуальні функції реалізуються шляхом здійснення відповідними суб'єктами прав і обов'язків (повноважень), закріплених у кримінальному процесуальному законодавстві. Суд наділений повноваженнями як щодо здійснення основної функції - правосуддя, так і інших функцій, які виконуються на різних стадіях кримінального провадження.

Основними кримінально-процесуальними функціями, які реалізуються судом на стадії підготовчого провадження, є правосуддя і судовий контроль. Правосуддя $€$ основною кримінально-процесуальною функцією, яку здійснює суд через реалізацію у встановленій законом процесуальній формі повноважень щодо з'ясування обставин, які підлягають доказуванню, та інших обставин, які мають значення для кримінального провадження, і вирішення обвинувачення по суті з ухваленням законного, обгрунтованого і справедливого судового рішення.

Судовий контроль як напрям діяльності характеризується спрямованістю на досягнення за допомогою власних засобів загальних завдань кримінального провадження, а також власних завдань: забезпечення законності та обгрунтованості кримінально-процесуальних рішень, законності процесуальних дій. Функція судового контролю здійснюється слідчим суддею (у досудовому провадженні) та судом (у підготовчому судовому провадженні, судовому розгляді, судово-контрольних стадіях кримінального провадження) [6, с. 119-120].

На стадії підготовчого провадження після надходження від прокурора до суду обвинувального акту клопотання про застосування примусових заходів медичного або виховного характеру чи клопотання про звільнення від кримінальної від- 
повідальності суд у підготовчому судовому засіданні з урахуванням думок учасників судового провадження вирішує питання щодо можливості призначення судового розгляду чи наявності підстав для прийняття інших рішень, передбачених кримінальним процесуальним законом.

Як зазначає О.Ф. Шминдрук, процедура підготовчого провадження в суді першої інстанції має змагальний характер і складається з кількох етапів: 1) дії, пов'язані з підготовкою підготовчого судового засідання; 2) власне підготовче судове засідання; 3) (факультативний) - ознайомлення учасників із матеріалами кримінального провадження (кримінальною справою) [7, с. 13].

O.В. Бабаєва виокремила такі етапи (частини) підготовчого провадження: 1) початковий етап, який передує підготовчому судовому засіданню та покликаний створити організаційні й процесуальні передумови для його проведення. Ця частина включає отримання та реєстрацію матеріалів кримінального провадження в автоматизованій системі документообігу суду та визначення складу суду, призначення суддею дати підготовчого судового засідання та виклик сторін; 2) основний етап, який полягає у проведенні підготовчого судового засідання. Цей етап займає центральне місце у структурі підготовчого провадження, адже найбільшою мірою розкриває зміст правовідносин, які визначають сутність цієї стадії; 3) заключний етап, який полягає у прийнятті підсумкового рішення та вчиненні інших дій, зумовлених завданнями підготовчого провадження та його процесуальною формою (загальним або диференційованим порядком) [8, с. 5-6, 14-15].

На першому етапі підготовчого провадження за розпорядженням головуючого секретар судового засідання повідомляє про день, час і місце проведення підготовчого судового засідання прокуроpa, обвинуваченого, захисника, потерпілого, його представника та законного представника, цивільного позивача, його представника та законного представника, цивільного відповідача та його представника, представника юридичної особи, щодо якої здійснюється провадження, шляхом направлення повідомлення чи судового виклику в порядку, визначеному КПК. Повідомлення чи судовий виклик повинні бути надіслані у строки, що дають реальну можливість забезпечити своєчасність їх отримання та реалізації права осіб на участь у підготовчому судовому засіданні.

Під час підготовчого судового засідання можуть бути постановлені ухвали про відмову в затвердженні угоди, про закриття кримінального провадження, про повернення обвинувального акту, клопотання про застосування примусових заходів медичного або виховного характеру прокурору чи про направлення обвинувального акту, клопотання про застосування примусо- вих заходів медичного або виховного характеру до відповідного суду для визначення підсудності у випадку встановлення непідсудності кримінального провадження. Прийняття цих рішень $є$ реалізацією судом повноважень щодо здійснення функції судового контролю на стадії підготовчого провадження.

У КПК також фактично передбачено перенесення здійснення функції судового контролю зі стадії досудового розслідування у стадію підготовчого провадження щодо розгляду скарг на рішення, дії чи бездіяльність слідчого, дізнавача або прокурора, які не розглядаються під час досудового розслідування (ч. 2 ст. 303 КПК), а також рішень прокурора, слідчого, дізнавача про відмову у визнанні потерпілим і рішень, дій чи бездіяльності слідчого, дізнавача або прокурора при застосуванні заходів безпеки (ч. 3 ст. 303 КПК). Так само під час підготовчого провадження в суді можуть бути подані заперечення проти ухвал слідчого судді, оскарження яких не передбачено частиною першою статті 309 КПК під час досудового розслідування (ч. 3 ст. 309 КПК). Проте спеціальна регламентація розгляду судом таких скарг і заперечень на стадії підготовчого провадження у КПК відсутня, що ускладнює захист прав і законних інтересів учасників кримінального провадження в цій частині, у зв'язку з чим висловлюється обгрунтована критика науковців.

Так, О.В. Бабаєва аргументує недоцільність розгляду під час підготовчого провадження скарг на рішення, дії чи бездіяльність слідчого чи прокурора та пропонує виключити зі статті $303 \mathrm{KПК}$ частини 2 та 3 щодо розгляду скарг у підготовчому судовому засіданні [8, с. 7, 16]. М.П. Тахтаровим обгрунтована позиція про неможливість розгляду під час підготовчого провадження заперечень на ухвали слідчого судді, які не підлягають оскарженню під час досудового розслідування відповідно до ст. 309 КПК, та запропоновано виключити з тексту ч. 3 ст. 309 КПК положення відповідного змісту [9, с. 4].

На неефективність відповідних положень КПК вказується і в постанові Великої Палати Верховного Суду від 23 травня 2018 року: «Частина третя статті 309 КПК встановлює, що інші ухвали слідчого судді оскарженню не підлягають і заперечення проти них можуть бути подані під час підготовчого провадження в суді. Тобто, у випадку незгоди сторін з іншими ухвалами слідчого судді законність цих ухвал підлягає перевірці судом першої інстанції під час підготовчого провадження. Велика Палата Верховного Суду погоджується з викладеними в ухвалі від 06 березня 2018 року аргументами колегії суддів Касаційного кримінального суду про те, що зазначена перевірка не є ефективним засобом захисту від можливого порушення статті 8 Конвенції про 
захист прав людини і основоположних свобод (далі - Конвенція) і статті 1 Першого протоколу до Конвенції, оскільки, по-перше, не в усіх випадках кримінальні справи, у яких було здійснено позапланові перевірки, будуть передані до суду 3 обвинувальним актом. По-друге, підготовче засідання в суді першої інстанції, навіть якщо обвинувальний акт передано до суду, може відбутися запізно для того, щоб бути здатним виправити порушення. По-третє, під час підготовчого судового засідання суддя не має повноважень вчиняти дії та приймати рішення, які можуть призвести до виправлення порушення Конвенції, спричиненого втручанням з боку держави» [10].

Реалізація функції судового контролю на стадії підготовчого провадження передбачена також і положеннями ч. 3 ст. 315 КПК, де зазначається, що під час підготовчого судового засідання суд за клопотаннями учасників судового провадження має право обрати, змінити чи скасувати заходи забезпечення кримінального провадження, в тому числі запобіжний захід, обраний щодо обвинуваченого. При розгляді таких клопотань суд додержується правил, передбачених розділом II КПК. Проте положення третього речення частини третьої статті 315 КПК, де вказано, що «за відсутності зазначених клопотань сторін кримінального провадження застосування заходів забезпечення кримінального провадження, обраних під час досудового розслідування, вважається продовженим», було визнано Конституційним Судом України таким, що не відповідає Конституції України (є неконституційним) [11].

Серед іншого Конституційний Суд України зазначив, що «коли суддя за відсутності клопотань сторін (прокурора) ініціює питання продовження тримання обвинуваченого під вартою або домашнім арештом, він виходить за межі судової функції і фактично стає на сторону обвинувачення, що $€$ порушенням принципів незалежності і безсторонності судової влади» [11].

Окрім функції судового контролю, на стадії підготовчого провадження судом реалізується i функція правосуддя, зокрема у випадках ухвалення на цій стадії обвинувального вироку на підставі угоди сторін (п. 1 ч. 3 ст. 314 КПК). Вирішення питання про затвердження угоди про примирення між потерпілим і підозрюваним чи обвинуваченим і угоди між прокурором і підозрюваним чи обвинуваченим про визнання винуватості здійснюється судом під час підготовчого судового засідання в особливому порядку з додержанням вимог, передбачених ст.ст. 468-475 КПК. Діяльність суду при цьому спрямована на з'ясування добровільності позицій обвинуваченого та потерпілого щодо укладення угоди та роз'яснення їм правових наслідків її затвердження. Якщо суд переконається, що угода може бути затверджена, він ухвалює вирок, яким затверджує угоду і призначає узгоджену сторонами міру покарання.

Вирок на підставі угоди повинен відповідати загальним вимогам до обвинувальних вироків 3 урахуванням особливостей, передбачених ч. 3 ст. 475 КПК. Таким чином, на стадії підготовчого провадження судом реалізується функція правосуддя при здійсненні повноважень щодо затвердження вироком угоди про визнання винуватості між прокурором і підозрюваним чи обвинуваченим та угоди про примирення між потерпілим i підозрюваним чи обвинуваченим, оскільки в зазначених випадках вирішується питання про обвинувачення та ухвалюється вирок суду.

На стадії підготовчого провадження судом також виконуються повноваження забезпечувального характеру щодо здійснення правосуддя (призначення судового розгляду на підставі обвинувального акту та вирішення питань, пов' язаних із підготовкою до судового розгляду). У разі відповідності обвинувального акту, клопотання про застосування примусових заходів медичного або виховного характеру вимогам кримінального процесуального закону за відсутності підстав для прийняття інших рішень суд проводить підготовку до судового розгляду, вирішує необхідні питання, створюючи умови для повного, всебічного й об'єктивного розгляду обставин у судовому розгляді та дослідження доказів, а також ухвалення законного, обгрунтованого і справедливого судового рішення.

Особлива роль при проведенні такої підготовки належить розгляду клопотань учасників судового провадження про здійснення судового виклику певних осіб до суду для допиту та витребування певних речей чи документів. Відхилення судом клопотань учасників судового провадження про допит певних осіб, дослідження доказів або вчинення інших процесуальних дій на підтвердження чи спростування обставин, з'ясування яких могло мати істотне значення для ухвалення законного, обгрунтованого та справедливого судового рішення, згідно з вимогами п. 1 ч. 1 ст. 410 КПК визнається неповнотою судового розгляду та є підставою для скасування або зміни судового рішення при розгляді справи в суді апеляційної інстанції [12].

Про необхідність розширення повноважень суду щодо здійснення підготовчих дій до судового розгляду були висловлені слушні пропозиції В.0. Попелюшком [13, с. 44-48] та Ю.М. Мирошниченком [14, с. 142-144]. У цьому аспекті О.Ф. Шминдрук пропонує передбачити обов'язок сторін у підготовчому судовому засіданні надавати суду наявні в них матеріали кримінального провадження, які вони мають намір використати в суді, та обгрунтовує положення про те, що суд повинен для забезпечення передбаченого ст. 317 КПК права сторін на ознайомлення з матеріалами криміналь- 
ного провадження (кримінальною справою) і можливості визначитися з обсягом доказів, які будуть досліджуватися в суді, та порядком їх дослідження (ст. 349 КПК), а з поданих сторонами матеріалів кримінального провадження і матеріалів підготовчого провадження сформувати кримінальну справу [7, с. 5, 12]. Такі пропозиції заслуговують на увагу в аспекті спрямування на забезпечення ефективності майбутнього судового розгляду.

Запропоновані вдосконалення процесуального закону спрямовані на забезпечення реалізації на стадії підготовчого провадження засад змагальності й рівності сторін та узгоджуються із практикою Європейського суду з прав людини (далі ЄСПЛ). Так, у рішенні ЄСПЛ у справі «Салов проти України» (заява № 65518/01) від 6 вересня 2005 року зазначено: «Суд повторює, що принцип рівності сторін у процесі є лише одним з елементів більш широкого поняття «справедливого судового розгляду», яке також включає фундаментальний принцип змагальності процесу (див. Ruiz-Mateos v. Spain, рішення від 23 червня 1993 року, Cерія А, № 262, с. 25 , параграф 63).

Принцип рівності сторін у процесі в розумінні «справедливого балансу» між сторонами вимагає, щоб кожній стороні надавалася розумна можливість представити справу в таких умовах, які не ставлять цю сторону у суттєво невигідне становище відносно іншої сторони (див. Dombo Beheer B. V. v. the Netherlands, рішення від 27 жовтня 1993 року, серія А, № 274, с. 19, параграф 33 та Ankerl v. Switzerland, рішення від 23 жовтня 1996 року, Reports 1996-V, ст. 1567-68, параграф 38). Принцип змагальності процесу означає, що кожній стороні повинна бути надана можливість ознайомитися з усіма доказами та зауваженнями, наданими іншою стороною, і відповісти на них (див. рішення у справі Ruiz-Mateos, наведене вище, с. 25, параграф 63) [15].

Варто також звернути увагу на окремі питання щодо повноважень суду в підготовчому судовому засіданні при здійсненні кримінального провадження в особливих порядках із диференціацією процесуальної форми. В.О. Гринюк слушно зазначає, що в контексті встановлення обгрунтованості обвинувачення у підготовчому провадженні потребує вирішення на нормативному рівні питання регламентації процесуальних засобів такої перевірки та закріплення у ст. 297 КПК України обов'язку прокурора надати разом із клопотанням i додатками до нього матеріали кримінального провадження (для розгляду клопотання про звільнення від кримінальної відповідальності); встановлення винятків у ст. 291 КПК України із правила щодо заборони подання інших документів до початку судового розгляду для обвинувальних актів, які направляються до суду з угодою, та розширення повноважень суду із розгляду клопотань і угод шляхом ініціювання й проведення допитів, дослідження документів, речових доказів, звукота відеозаписів [16, с. 23-24].

Д.О. Шумейко звертає увагу на певну специфіку підготовчого провадження за процедурою in absentia, яка вимагає від суду додаткових дій щодо забезпечення прав обвинуваченого та пропонує серед рішень, які можуть бути прийняті в підготовчому судовому засіданні, передбачити рішення про здійснення спеціального судового провадження [17, с. 607-611].

Необхідно зазначити і про право обвинуваченого у вчиненні злочину, за який передбачене покарання у вигляді довічного позбавлення волі, під час підготовчого судового засідання заявити клопотання про розгляд кримінального провадження стосовно нього судом присяжних (ч. 2 ст. 384 КПК). Це право повинне бути роз'яснене обвинуваченому судом на стадії підготовчого провадження для забезпечення здійснення судового розгляду й ухвалення судового рішення законним складом суду.

Відповідно до ч. 4 ст. 315 КПК під час підготовчого судового засідання суд має роз'яснити обвинуваченому у вчиненні злочину, за вчинення якого передбачено покарання у вигляді позбавлення волі на строк більше 10 років, право заявити клопотання про розгляд кримінального провадження стосовно нього колегіально судом у складі трьох суддів. Цю норму необхідно доповнити положенням про роз'яснення судом обвинуваченому у вчиненні злочину, за який передбачене покарання у вигляді довічного позбавлення волі, права заявити клопотання про розгляд кримінального провадження стосовно нього судом присяжних.

Висновки. Основною функцією суду, яка реалізується на стадії підготовчого провадження, $€$ судовий контроль, при здійсненні якого можуть бути прийняті рішення про відмову в затвердженні угоди; про закриття кримінального провадження; про повернення обвинувального акту, клопотання про застосування примусових заходів медичного або виховного характеру прокурору чи про направлення обвинувального акту, клопотання про застосування примусових заходів медичного або виховного характеру до відповідного суду для визначення підсудності у випадку встановлення непідсудності кримінального провадження.

Функція правосуддя реалізується судом на стадії підготовчого провадження при здійсненні повноважень щодо затвердження вироком угоди про визнання винуватості між прокурором і підозрюваним чи обвинуваченим та угоди про примирення між потерпілим і підозрюваним чи обвинуваченим, оскільки в зазначених випадках вирішується питання про обвинувачення та ухвалюється вирок суду. На стадії підготовчого провадження судом також виконуються повноваження 
забезпечувального характеру щодо здійснення правосуддя (призначення судового розгляду на підставі обвинувального акту та вирішення питань, пов'язаних із підготовкою до судового розгляду). Потребують спеціальної регламентації у статтях глави $27 \mathrm{KПК} \mathrm{«Підготовче} \mathrm{провадження»}$ повноваження суду щодо вирішення питань про здійснення спеціального судового провадження та забезпечення законного складу суду.

\section{Iimepamypa}

1. Строгович М.С. Курс советского уголовного процесса: в 2 т. Т. 1. Основные положения науки советского уголовного процесса. Москва : Наука, 1968. 468 с.

2. Элькинд П.С. Сущность советского уголовно-процессуального права. Ленинград : Изд-во ЛГУ, $1963.172 \mathrm{c}$.

3. Зеленецкий В.С. Функциональная структура прокурорской деятельности : учебное пособие. Харьков : Изд-во ХЮИ, 1978. $78 \mathrm{c.}$

4. Альперт С.А. Кримінально-процесуальні функції: поняття, система, суб’єкти : конспект лекцій. Харків : Національна юридична академія України, $1995.28 \mathrm{c}$.

5. Попелюшко В.О. Функція захисту в кримінальному судочинстві України: правові, теоретичні та прикладні проблеми : монографія. Острог : Вид-во Національного ун-ту «Острозька академія», 2009. 634 с.

6. Гловюк І.В. Кримінально-процесуальні функції: теорія, методологія та практика реалізації на основі положень Кримінального процесуального кодексу України. 2012 рік. Монографія. Одеса : Юридична літератуpa, 2015. $712 \mathrm{c.}$

7. Шминдрук О.Ф. Підготовче провадження в кримінальному процесі України : автореф. дис. ... канд. юрид. наук: 12.00.09. Київ, 2016. 19 с.

8. Бабаєва О.В. Підготовче провадження в системі стадій кримінального процесу України : автореф. дис. ... канд. юрид. наук: 12.00.09. Харків, 2019. 20 с.

9. Тахтаров М.П. Прокурор у підготовчому судовому провадженні : автореф. дис. ... канд. юрид. наук: 12.00.09. Харків, 2019. 20 с.

10. Постанова Великої Палати Верховного Суду від 23 травня 2018 року у справі № $243 / 6674 / 17-\kappa$, провадження № 13-16сво18. URL: http://www.reyestr.court. gov.ua/Review/74475959 (дата звернення: 20.12.2020).

11. Рішення Конституційного Суду України у справі за конституційним поданням Уповноваженого Верховної Ради України з прав людини щодо відповідності Конституції України (конституційності) положення третього речення частини третьої статті 315 Кримінального процесуального кодексу України від 23 листопада 2017 року № 1-p/2017. URL: http://www. ccu.gov.ua/sites/default/files/docs/1-p 2017.pdf (дата звернення: 20.12.2020).

12. Про порядок здійснення підготовчого судового провадження відповідно до Кримінального процесуального кодексу України : лист Вищого спеціалізованого суду України з розгляду цивільних і кримінальних справ від 3 жовтня 2012 року № 223-1430/0/4-12. URL: http://zakon4.rada.gov.ua/laws/show/v143074012 (дата звернення: 20.12.2020).

13. Попелюшко В.О. Формування кримінальної справи на стадії судового провадження. Юридичний ча- сопис Національної академії внутрішніх справ. 2013. № 1. C. 44-49.

14. Мирошниченко Ю. Проблеми судового розгляду в кримінальному провадженні: організаційно-підготовчий аспект. Слово Національної школи суддів України. 2013. № 4(5). С. 139-144.

15. Рішення Європейського суду з прав людини у справі «Салов проти України» (Заява № 65518/01) від 6 вересня 2005 року. URL: https://zakon.rada. gov.ua/laws/show/980 428\#Text (дата звернення: 20.12.2020).

16. Гринюк В.О. Функція обвинувачення в кримінальному судочинстві України: правові, теоретичні та практичні проблеми реалізації : автореф. дис. д-ра юрид. наук: 12.00.09. Київ, 2017. 36 с.

17. Шумейко Д.О. Підготовче судове провадження у спеціальному кримінальному провадженні. Порівняльно-аналітичне право. 2020. № 1. С. 607-611. URL: http://pap-journal.in.ua/wp-content/uploads / 2020/08/1-1.pdf (дата звернення: 20.12.2020).

\section{Анотація}

Сиза Н. П. Реалізація судом кримінально-процесуальних функцій на стадії підготовчого провадження. - Стаття.

У статті розглянуто особливості реалізації кримінально-процесуальних функцій на стадії підготовчого провадження. Встановлено, що основною функцією суду на стадії підготовчого провадження є судовий контроль. При здійсненні цієї функції приймаються рішення про відмову в затвердженні угоди, про закриття кримінального провадження, про повернення обвинувального акту, клопотання про застосування примусових заходів медичного або виховного характеру прокурору чи направлення обвинувального акту, клопотання про застосування примусових заходів медичного або виховного характеру до відповідного суду для визначення підсудності. Звернено увагу на проблематику розгляду судом на стадії підготовчого провадження скарг на рішення, дії чи бездіяльність слідчого, дізнавача або прокурора, що передбачено ч.ч. 2 і 3 ст. 303 КПК. Зазначено про неефективність положень ч. 3 ст. 309 КПК, які передбачають можливість подання заперечень проти ухвал слідчого судді під час підготовчого провадження.

Розкрито особливості реалізації судом функції правосуддя на стадії підготовчого провадження при ухваленні обвинувального вироку на підставі угоди у кримінальному провадженні. 3'ясовано, що на стадії підготовчого провадження судом також виконуються повноваження забезпечувального характеру щодо здійснення правосуддя (призначення судового розгляду на підставі обвинувального акту та вирішення питань, пов'язаних із підготовкою до судового розгляду).

Звернено увагу на окремі питання, які потребують вирішення у підготовчому судовому засіданні при здійсненні кримінального провадження в особливих порядках, 3 диференціацією процесуальної форми. Запропоновано передбачити у главі 27 КПК «Підготовче провадження» норми, які регламентують вирішення судом питань про здійснення спеціального судового провадження та забезпечення законного складу суду.

Ключові слова: кримінально-процесуальні функції, стадія підготовчого провадження, повноваження суду, судовий контроль, правосуддя. 


\section{Summary}

Syza N. P. Criminal procedural functions implementation by the court in the preparatory stage of the proceedings. - Article.

The peculiarities criminal procedural functions implementation by the Court in the Preparatory stage of the proceedings deals in this article. The main function of the Court in the Preparatory stage of the proceedings is judicial control. The decisions of refuse to approve the agreement, close the criminal proceedings, return the indictment to the prosecutor or send the indictment to determine jurisdiction are made to exercise of this function. The issue of consideration by the Court in the Preparatory stage of the proceedings of complaints against decisions, actions or omissions of the investigator, interrogator or prosecutor, as provided for in parts 2 and 3 of Art. 303 of the Criminal Procedure Code (CPC), is considered. Ineffectiveness of the provisions of Part 3 of Art. 309 of the CPC, which provide for the possibility of filing objections against the decisions of the investi- gating judge during the Preparatory stage of the proceedings, are shown.

The peculiarities of the Court's implementation of the function of justice in the Preparatory stage of the proceedings in the adoption of a conviction on the basis of an agreement in criminal proceedings are revealed. The court also exercises precautionary powers to administer justice (appointing a trial on the basis of an indictment and resolving issues related to preparation for trial) in the preparatory proceedings.

Certain issues that need to be resolved in the Preparatory stage of the proceedings in the implementation of criminal proceedings in a special manner, with the differentiation of the procedural form are considered. It is proposed to include in Chapter 27 of the CPC "Preparatory Proceedings" the rules governing the decision of the Court on the implementation of special court proceedings and the legal composition of the court.

Key words: criminal procedure functions, Preparatory stage of the proceedings, powers of the court, judicial control, justice. 